\title{
ANALYTICAL FRAMEWORK AND STUDENT PERCEPTIONS: ASSESSING THE QUALITY OF DOCTORAL EDUCATION IN ACCOUNTING IN IRELAND
}

\author{
Anne Marie Ward \\ Ulster University \\ Louise Gorman \\ Technological University Dublin \\ and \\ Niamh M. Brennan \\ University College Dublin
}

\begin{abstract}
$\mathrm{T}$ o examine the quality of doctoral education in accounting in higher education institutions (HEIs) in Ireland, we develop an analytical framework from the relevant literature and the principles of quality doctoral education included in the Higher Education Authority's (HEA) National Framework for Doctoral Education (NFDE). Our analytical framework identifies 16 measurable indicators of quality doctoral education classified into four dimensions: context, inputs, processes and outcomes. Compliance with the quality indicators is verified by coding HEI websites and prospectuses. Deeper insights on the indicators of quality doctoral education are obtained from semi-structured interviews with accounting doctoral students. Our findings shed valuable insights on the quality of doctoral education in accounting in an Irish context. Currently, doctoral education in accounting in Ireland is widely available, standardised and consistent with the principles of the NFDE. This suggests a quality doctoral education system in accounting in Ireland. However, our investigation of the individual components of quality identifies areas for improvement.
\end{abstract}

Keywords: analytical framework; doctoral education; quality standards; accounting; Ireland; student perceptions 
Ward et al.

\section{INTRODUCTION}

The quality of doctoral education is of interest to students, academic staff, higher education institutions (HEIs) ${ }^{1}$ and policymakers (Cheng, Taylor, Williams and Tong, 2016). The subject is of particular relevance in Ireland as the Irish government has identified doctoral education as important for Ireland's future national innovation (Benito and Romera, 2013; Higher Education Authority, 2017). To promote growth of doctoral education in Ireland, the Irish government has called for a consistent quality framework and greater collaboration among providers to position Ireland as a leader of doctoral education (Department of Education and Skills, 2011). Quality doctoral provision is important for the accounting discipline to ensure academically qualified faculty to educate future accounting professionals and to educate future doctorally trained accounting faculty. Prior research identifies problems at all stages of the accounting doctoral process and high attrition rates (Behn, Carnes, Krull Jr, Stocks and Reckers, 2008). The consequence is significant for the accounting discipline as authors argue the dearth of accounting doctoral graduates is at crisis level (Fogarty and Markarian, 2007; Irvine, Moerman and Rudkin, 2010; Beattie and Smith, 2012; Plumlee and Reckers, 2014; Smith and Urquhart, 2018). The shortage has long-term ramifications for accounting as an academic discipline (Fogarty and Markarian, 2007; Plumlee and Reckers, 2014; Smith and Urquhart, 2018), as a teaching discipline (Boyle, Carpenter, Hermanson and Mensah, 2013) and for the legitimacy of the accounting profession (Beattie and Smith, 2012).

There is little literature on the quality of doctoral programme provision in accounting in general and specifically in Ireland. The concept and measurement of quality doctoral education is subjective and also has received little attention in the literature (Cheng et al., 2016). Our paper addresses the question: 'Do HEIs in Ireland provide quality doctoral education in accounting?'

We make three contributions to the literature. First, we use a mechanistic approach to develop an analytical framework to measure quality accounting doctoral education. Mechanistic approaches typically measure the quality of education provision against predefined benchmarks established by educational experts, for example, the UK Quality Assurance Agency (Cheng, 2011). We develop our analytical framework from the literature and from the Higher Education Authority's (2017) National Framework for Doctoral Education (NFDE). ${ }^{2}$ The NFDE captures the educational objectives set out in the Irish Universities Association (2015) PhD Graduate Skills Statement. The NFDE is designed to guide HEIs when creating doctoral education provision. The framework consists of nine principles. ${ }^{3}$ Our analytical framework maps the nine principles to Cheng et al.'s (2016) four dimensions of quality education - context, inputs, processes and outcomes. Second, to evaluate whether HEIs in Ireland provide quality accounting doctoral education, we code HEI websites and prospectuses to determine if the provision on offer complies with our analytical framework for quality doctoral education. Joseph, Yakhou and Stone (2005) criticise this type of mechanistic approach as there is insufficient consideration of students. Therefore, third, we use a humanistic approach to gain deeper insights into student perceptions of the quality of doctoral education in accounting. This involves semi-structured interviews with 36 accounting doctoral students who 
are currently or were formerly enrolled on an accounting doctoral programme in an Irish HEI.

Our research has important policy implications. Our results suggest that doctoral provision is widespread, standardised and, in general, meets the mechanistic requirements in our analytical framework for quality doctoral education. Three areas appear to fall short: research environment, induction and course provision. Research environment is hampered by the low number of doctoral-qualified accounting faculty and lack of professors of accounting. Only half of the HEIs refer to induction on their websites or in their prospectuses. Finally, though most doctoral students express satisfaction with many aspects of their doctoral education, several mention that courses are not tailored to the needs of accounting research. Therefore, HEIs generally meet the requirements of our analytical framework for quality doctoral education and students are positive about their experiences. However, a tick-box approach is evident. While the structures and resources are available, the environment is not deemed to be conducive to research and resources, though provided, are not sufficiently tailored to meet the needs of the accounting discipline.

We structure the paper as follows. The next section evaluates prior literature on quality in doctoral education by reference to mechanistic and humanistic approaches. We consider the context of our study and overview the type of doctoral programmes ${ }^{4}$ provided by HEIs in Ireland. We outline the methodology to address our research questions, including justification of our analytical framework for quality accounting doctoral education. In the penultimate section, we present our findings of the analysis of websites and prospectuses (mechanistic evidence) and evaluate whether accounting doctoral students consider their current programme/ course provision meets their educational needs (humanistic evidence). We end our paper with some concluding comments.

\section{LITERATURE REVIEW}

Defining and measuring quality in HEIs is highly subjective (Wittek and Kvernbekk, 2011) and open to variation in definition depending on the stakeholder (Chaubey and Krivacek, 2016). Stakeholders include educational experts and students. Educational experts and policymakers create standards to improve the quality of education. Compliance with these standards is regarded as evidence of quality. However, when it comes to education, the primary stakeholders are students. HEIs should create value for students in terms of their learning and human capital (Langstrand, Cronemyr and Poksinska, 2015) and should be accountable for quality education to students (Chen, Chen and Chen, 2014). Hence, the quality of education should encapsulate student views. Two approaches to defining and measuring quality can be classified as either mechanistic or humanistic.

\section{Measuring Quality Doctoral Education: Mechanistic Approaches}

Mechanistic approaches are typically used by policymakers and management to evaluate quality education provision. The approach involves determining quality measures that are quantifiable. There are two types of mechanistic approach. The 
Ward et al.

first uses measures that capture input or investment in education. Examples include the teacher-student ratio, the number of contact hours spent on programme delivery or the monetary investment in an educational programme (Langstrand et al., 2015). Management use these quality metrics to market their programmes to attract international students (Cheng et al., 2016). Whilst these measures may be correlated with quality, they are not measures of quality (Langstrand et al., 2015). The second mechanistic approach evaluates programme provision against pre-defined targets or principles. For example, the UK Quality Assurance Agency focuses on quality enhancement to score the quality of university teaching and learning (Cheng, 2011). In support of this approach, Langstrand et al. (2015) report a link between effective programme design and student learning, evidenced by improved examination performance and stronger student evaluations.

Joseph et al. (2005) argue that a mechanistic approach is flawed as it overly focuses on inputs and the views of education providers and does not consider the views of the primary stakeholders, students. However, despite not incorporating the views of students, studies report a link between effective programme design, and academic standards and student perceptions of quality doctoral education (Tsinidou, Georgiannis and Fitsilis, 2010; Morrison, Rudd, Zumeta and Nerad, 2011; Cheng, 2014).

\section{Measuring Quality Doctoral Education: Humanistic Approaches}

Humanistic approaches focus on the student perspective. This perspective assumes quality is achieved when students experience a transformative learning experience (Harvey, 2006). However, 'transformation' is difficult to define and conceptualise (Cheng, 2014). An alternative humanistic approach considers HEIs to be service providers, doctoral education to be a product and doctoral students to be consumers. Therefore, consumer satisfaction is a service outcome (Marzo-Navarro, PedrajaIglesias and Rivera-Torres, 2005; Guber, Fub, Voss and Zikuda, 2010) reflecting quality of the service (Nair, Murjocj and Mertova, 2011). Education policymakers in several countries adopt this view and gather information on student satisfaction as a means of holding HEIs accountable to the public for the funding received (e.g. the UK Student Satisfaction Survey). Student satisfaction surveys typically involve students evaluating lecturers, administrators, their departments and their institutions (Bruggen, Fouberr and Gremler, 2011). Survey components are aggregated into an overall satisfaction score (Douglas, Douglas, McClelland and Davies, 2014) used to create university rankings or league tables (Gibbons, Neumayer and Perkins, 2013). These tables differentiate HEIs and are an indicator of quality, reflecting fitness for purpose and value for money (Harvey, 2006). In support of this approach, some studies find an association between student satisfaction and quality education, measured as students' motivation levels and retention (Marzo-Navarro et al., 2005; Sum, McCaskey and Kyeyune, 2010; Kahu, 2013).

However, there are concerns about using student satisfaction to indicate quality. There is a lack of consensus about how to measure and assess satisfaction (Giese and Cote, 2000). Further, Nixon and Scullion (2010) consider the assumption that a highperforming HEI is one with satisfied students to be flawed as it does not incorporate academic standards. Collini (2012) notes that postgraduate study is not always an 
easy or happy experience. Students may encounter experiences that are emotionally challenging, but essential for their intellectual development, possibly resulting in lower satisfaction scores. Questions have also been raised about satisfaction surveys, as responses are influenced by external factors such as students' personal life and emotions (Williams, 2013; Cheng et al., 2016). In addition, satisfaction is a shortterm attitude that reflects opinion of an educational experience at one point in time (Summers, Waigandt and Whittaker, 2005). Therefore, over-emphasis on student satisfaction can threaten quality. A further risk of satisfaction surveys is that academics may challenge students less, so students feel happier and score courses and programmes higher in student satisfaction surveys. This contradicts the purpose of doctoral education, which is to challenge students, to train them to defend their work and contribute to new knowledge (Molesworth, Nixon and Scullion, 2009).

In the literature on expectancy value theory (Eccles and Wigfield, 2002), concerns are also raised about the use of student attitudes. Expectancy value theory predicts that student evaluations of quality may be affected by their initial preconceptions of quality related to the reputation of the HEI or preconceived notions of the doctoral educational experience. In support of this view, Ismail, Abdullah and Francis (2009) find that students' expectations of quality are formed prior to receiving education. Moreover, student perceptions of programme quality are difficult to isolate due to the blurring of the boundary between their programmes and their HEI (Vauterin, Linnanen and Marttila, 2011). In addition, some authors argue that using student views to compare educational quality across HEIs is not objective (Vauterin et al., 2011).

We propose a theoretical approach that combines both a mechanistic and humanistic approach to evaluate quality doctoral education in accounting in HEIs in Ireland. We adopt a two-stage evaluation process. We first develop an analytical framework based on quality standards established by education experts (mechanistic approach). However, we argue that an assessment of quality education should not be constrained to the components of our framework. Therefore, second, we elicit the views of doctoral students on their experience of the indicators in our framework (humanistic approach).

\section{CONTEXT: DOCTORAL EDUCATION IN IRELAND}

Historically, a high proportion of appointments to accounting faculty in Irish HEIs were professionally qualified accountants who did not have a doctorate (Paisey and Paisey, 2017). These appointees were encouraged to enrol for doctorates part-time but it was not a condition of their employment contract. However, the importance placed on global university rankings by universities, and the bid by ten institutes of technology (IoT) in Ireland to become technological universities (O'Brien, 2018), has increased the focus on research and changed recruitment policy. Most HEIs in Ireland now require appointees to have a doctoral qualification. This is a problem. Paisey and Paisey (2017) report heads of accounting departments in HEIs in Ireland experiencing a shortage of doctoral-qualified applicants when recruiting accounting faculty. Therefore, it is important that HEIs in Ireland provide high-quality accounting doctoral education that retains and motivates accounting doctoral students to 
Ward et al.

pursue a career in academia and provides them with the skills to continue independent research throughout their career.

\section{Profile of the Higher Education Sector in Ireland}

There are nine universities on the island of Ireland. Eight offer accounting doctoral education. There are fourteen IoTs in the Republic of Ireland and seven Colleges of Further Education in Northern Ireland. Two IoTs also offer accounting doctoral education. Therefore, there are ten options for accounting doctoral education in Ireland. All ten HEIs in Ireland offering accounting doctoral education provide a semi-structured approach to doctoral education, wherein the first year requires students to complete several courses. This homogeneity is expected, due to publication of the Irish Universities Association's (2015) PhD Graduate Skills Statement and the NFDE (Higher Education Authority, 2017). However, two HEIs also offer the traditional approach, which does not require students to attend courses, with students entirely reliant on their supervisors for guidance and training. Two HEIs offer the doctoral qualification by publication, though one restricts this offering to internal accounting staff only. There is no evidence of any HEI offering professional doctorate programmes in accounting. Duration of doctoral programmes is similar, though some HEIs advertise more flexible deadlines.

\section{Doctoral Student Population}

Though not identifying the number of students currently studying for doctorates in HEIs in Ireland, we obtained statistics from the HEA (Republic of Ireland) on all doctoral enrolments and graduations in the period 2004 to 2014. We contacted the accounting departments in Northern Irish universities for their doctoral enrolments. Table 1 shows 80 candidates enrolled for accounting doctoral education over the period 2004-2014, with 14 graduating in the same timeframe. These statistics suggest that 66 students (80 entrants less 14 graduations) are enrolled in accounting doctoral education in 2014. However, this number is likely to be overstated as the HEA does not record withdrawals. A central database of registered doctoral students does not exist to confirm our numbers. To obtain more information on current active accounting doctoral numbers, we mined HEI websites. Compared with the 66 possible students in Table 1, we find only 32 enrolled accounting doctoral students, eight of whom are in Northern Ireland. Three HEIs did not provide any details on accounting doctoral students.

TABLE I: SUMMARY OF ENROLMENTS TO AND GRADUATIONS FROM ACCOUNTING DOCTORAL EDUCATION AT HEIS IN IRELAND, 2004 TO 2014

\begin{tabular}{lccc}
\hline & $\begin{array}{c}\text { Republic of Ireland } \\
\text { No. }\end{array}$ & $\begin{array}{c}\text { Northern Ireland } \\
\text { No. }\end{array}$ & $\begin{array}{c}\text { Total } \\
\text { No. }\end{array}$ \\
\hline Enrolments (2004-20I4) & & & \\
Full-time & 50 & 5 & 55 \\
Part-time & 19 & 6 & 25 \\
Total & 69 & 11 & 80 \\
Graduations (2004-20I4) & 12 & 2 & 14 \\
\hline
\end{tabular}


Analytical Framework and Student Perceptions

\title{
RESEARCH QUESTIONS, ANALYTICAL FRAMEWORK AND DATA COLLECTION
}

\author{
Research Questions \\ Our overarching question is: 'Do HEIs in Ireland provide quality doctoral education \\ in accounting?' We address this with two research questions (RQ): \\ RQ1: Is doctoral education in accounting in Ireland in line with quality standards for \\ doctoral education? \\ RQ2: How do accounting doctoral students perceive the quality of doctoral education in \\ accounting in HEIs in Ireland? \\ Quality needs to be measured systematically and objectively to enable compari- \\ son across HEIs. Therefore, we first develop an analytical framework for measuring \\ quality doctoral education.
}

\section{Analytical Framework for Measuring Quality Doctoral Education}

Our analytical framework in Figure 1 operationalises quality doctoral education by classifying those measurable indicators considered in the literature and by policymakers to be related to quality doctoral education, into four dimensions of education: context, inputs, process and outcomes (Cheng et al., 2016).

Key determinants of the measurable indicators are the nine principles of quality doctoral education in the NFDE (Higher Education Authority, 2017). ${ }^{5}$ The nine principles guide educational institutions when designing quality doctoral education programmes. Therefore, adherence to the principles is considered an indicator of quality doctoral education. The nine principles do not always fit cleanly into one of the four dimensions of education: context, input, process and outcomes. For example, research facilities and supervision are both mentioned in the seventh principle. Research facilities could be classified into the 'context' and 'input' dimensions respectively. For simplicity, these are classified as part of the 'input' dimension to quality doctoral education only (Indicator G: Figure 1). Supervisory arrangements could fall within context, inputs or processes. Again, for simplicity, supervision is classified as part of the 'processes' dimension (Indicator J: Figure 1) of quality doctoral education. We now discuss the four dimensions in the context of our analytical framework.

\section{Quality Doctoral Education: Context}

The literature and the NFDE (Higher Education Authority, 2017) refer to the importance of context as an indicator of quality doctoral education. Students who undertake doctoral research in institutions characterised by research activity and high-quality research output may be better prepared for an academic career as they are more aware of the metrics and means of achieving research excellence (Sinclair, Barnacle and Cuthbert, 2014; Horta and Santos, 2016). Consistent with this, the NFDE states that quality in doctoral education is more achievable when 'doctoral education is conducted in a research environment with a high degree of academic quality and infrastructure and where it is consistent with institutional strategies. Academic quality includes quality supervision and training for supervisors' (Higher Education Authority 2017: Principle 6). 
Ward et al.

FIGURE I:ANALYTICAL FRAMEWORK FOR MEASURING QUALITY DOCTORAL EDUCATION

\begin{tabular}{|c|c|}
\hline Dimensions/Categories & Quality Measurement Indicator \\
\hline \multicolumn{2}{|l|}{ Context } \\
\hline \multirow[t]{4}{*}{ Research environment } & A. Proportion of staff engaged in research activity \\
\hline & Adequate training for supervisors \\
\hline & C. Doctoral research centre with international links \\
\hline & D. Opportunities to network with relevant peers \\
\hline \multicolumn{2}{|r|}{ 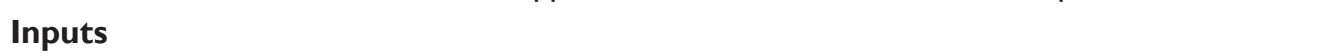 } \\
\hline \multirow[t]{2}{*}{ Admissions } & Research proposal required \\
\hline & Quality control over supervisor selection \\
\hline \multirow[t]{3}{*}{ Learning resources } & G. Facilities - work area, information technology (IT) and library \\
\hline & H. Specific courses tailored to the discipline \\
\hline & $\begin{array}{l}\text { I. Training on general and specific research methodology and } \\
\text { personal and professional development }\end{array}$ \\
\hline \multicolumn{2}{|l|}{ Processes } \\
\hline \multirow[t]{3}{*}{ Established structures } & One-to-one supervision with a topic expert \\
\hline & K. Periodic review and progress milestones \\
\hline & L. Defined procedure for qualification \\
\hline \multirow[t]{2}{*}{ Quality assurance } & M. An internal doctoral review panel including external experts \\
\hline & $\begin{array}{l}\text { N. A doctoral director - an expert focal point for } \\
\text { communication on doctoral education }\end{array}$ \\
\hline \multicolumn{2}{|l|}{ Outcomes } \\
\hline \multirow[t]{2}{*}{ Publishable thesis } & O. Use of external experts to examine the final thesis \\
\hline & Publications from the study \\
\hline
\end{tabular}

We include four measures of research environment in our analytical framework. The first evaluates staff engagement in research, which is proxied by the proportion of research-trained academic staff in the accounting department (Indicator A: Figure 1). The quality of academic staff is a marker of quality education (Tsinidou et al., 2010) and can reflect the research environment. The second indicator is training for doctoral supervisors (Indicator B: Figure 1). The literature suggests a link between supervisor training and timely completion of higher research degrees (Hammond, Ryland, Tennant and Boud, 2010). Training may lead to positive and effective supervision (Kiley, 2011), thereby creating a conducive environment for quality doctoral education. The third context quality indicator is a doctoral research centre with links to international research (Indicator C: Figure 1). The NFDE states that a principle of doctoral education is that it 'is conducted in a learning community where sufficient critical mass of internationally recognised research activity exists to allow students to gain access to a training programme of appropriate breadth and to interact with peers engaged in their field, nationally and internationally.' (Higher Education Authority, 2017: Principle 4). Therefore, a centre for doctoral education fostering international links creates a critical mass that ensures a pooling of resources to better afford the financial costs of maintaining international links. 
The final quality indicator of context is providing opportunities to network (Indicator D: Figure 1). Having opportunities to network with peers can positively influence completion rates as doctoral students gain both knowledge and support (Amundsen and McAlpine, 2009; Sweitzer, 2009; McAlpine and Amundsen, 2012). Consistent with this prediction, Bolli, Agasisti and Johnes (2015) report a link between on-site graduate conferences and completion rates in US HEIs.

\section{Quality Doctoral Education: Inputs}

The NFDE recommends that 'the admission of doctoral students takes into account preparedness of the applicant, the availability of qualified, competent and accessible supervision and the resources necessary to conduct the research' (Higher Education Authority, 2017: Principle 7). Therefore, in our analytical framework, we identify two input categories affecting the quality of doctoral education - the admissions policy and learning resources in support of doctoral education. An appropriate admissions policy ensures that appropriately qualified individuals who are prepared for their programme gain admittance (de Valero, 2001). In support of this view, Humphrey, Marshall and Leonardo (2012) find a positive association between the requirement to complete a project plan and timely completion. Therefore, the first measure indicating input quality is the requirement by HEIs for applicants to prepare a research proposal (Indicator E: Figure 1). This forces applicants to select a topic of interest, a factor linked to timely doctoral completion (Turner and McAlpine, 2011; McAlpine, 2012), to write it up in a manner that is consistent with academic writing, also related to timely doctoral completion (Wisker, Robinson, Vernon, Creighton and Warnes, 2003) and to commit time to their research in advance of their programme. The second indicator of admissions quality is a system in HEIs that vouches the quality of supervisors (Indicator F: Figure 1).

The second input category is learning resources. Three measurable indicators are used to capture information on the quality of learning resources (Indicators G, $\mathrm{H}$ and I: Figure 1). In the US, Bolli et al. (2015) find that facilities and dedicated workspaces enhance completion rates. Tsinidou et al. (2010) report that academic and library services are indicative of quality education. Therefore, the third input measure of quality doctoral education is the availability of appropriate workspaces, IT and library facilities (Indicator G: Figure 1).

Learning resources also include the courses on offer by HEIs. The traditional doctorate by thesis has been described as producing researchers that are narrow and specialised, inexperienced in interdisciplinary work, and lacking a broad array of general skills (Usher, 2002). Yet the skills students require to complete their doctorate are not divorced from the research workplace and other potential employment situations (Borthwick and Wissler, 2003). Such skills include measurement and analytical skills (Elliott and Jacobson, 2002), critical thinking, problem-solving, ICT literacy and knowledge management (Howieson, 2003). Cheng et al. (2016) find that both doctoral students and supervisors consider that research training is key to quality doctoral education (see also Tsinidou et al., 2010). Humphrey et al. (2012) report a link between research training and timely doctoral completion. Policymakers also recognise the importance of research training. The NFDE stipulates that: 
Ward et al.

\begin{abstract}
'Doctoral education increases significantly students' depth and breadth of knowledge of their discipline and develops their expertise in research methodology which is applicable to both a specific project and a wider context. It provides a high-quality research experience, training (including a formalised integrated programme of personal and professional development) and output consistent with international norms and best practice' (Higher Education Authority, 2017: Principle 3).
\end{abstract}

In addition, Principle 5 states 'recognising that each doctorate is unique, doctoral education is also flexible so as to support students within individual disciplines or within interdisciplinary or multidisciplinary groups' (Higher Education Authority, 2017: Principle 5). Quality doctoral education is therefore more likely when specialised training is provided for the discipline (Indicator H: Figure 1) and when general and professional development courses are also included (Indicator I: Figure 1).

\title{
Quality Doctoral Education: Processes
}

Our analytical framework for quality doctoral education suggests two categories of process quality - established structures and quality assurance. Established structures is identified as a principle of quality doctoral education by the NFDE:

'Doctoral education is supported by established structures with:

- $\quad$ supervision by a principal supervisor(s), normally with a supporting panel approved by the institution;

- $\quad$ formal monitoring of progress to completion against published criteria, supported by institutional arrangements;

- clearly defined examination processes, involving external examiners, assessment criteria and declared outcomes.' (Higher Education Authority, 2017: Principle 8).

We include three measurable indicators of process quality in terms of established structures - supervision, periodic reviews and final examination (Indicators J, K and L: Figure 1).

Humphrey et al. (2012) find a positive association between having a supervisory team and timely completion. Cheng et al. (2016) note that both doctoral students and supervisors consider access to disciplinary experts key to quality doctoral education. In addition, the NFDE states that doctoral programmes should provide 'supervision by a principal supervisor(s)' (Higher Education Authority, 2017: Principle 8). Therefore, the first process quality indicator is that doctoral education provides one-to-one supervision with a topic expert (Indicator J: Figure 1).

Tsinidou et al. (2010) conclude that curriculum structure contributes to quality in education. Consistent with this view, McAlpine and Norton (2006) investigate doctoral attrition rates in the US, the UK, Australia and Canada, finding inclusion of more regular progress reviews positively impacts and may alleviate non-completion. Therefore, the second process quality indicator relating to established structures is that doctoral education has formal systematic reviews and progress milestones, such as initial reviews, six-monthly reviews or confirmation (Indicator $\mathrm{K}$ : Figure 1), and finally that there is a defined procedure for qualification (Indicator L: Figure 1). 
A further key requirement of quality doctoral education is having 'a robust quality assurance system [that] underpins all doctoral provision' (Higher Education Authority, 2017: Principle 9). This is evidenced where the HEI has an internal doctoral review panel including external experts (Indicator M: Figure 1) and where the HEI has a dedicated director of doctoral education or equivalent as an expert focal point for communication on doctoral education (Indicator N: Figure 1).

\section{Quality Doctoral Education: Outcomes}

The first principle of the NFDE is 'the core of doctoral education is deep engagement with a question, problem or hypothesis at the frontier of knowledge, and advancement of this frontier under the guidance of expert and committed supervision. To be awarded a doctoral degree, the candidate must have made an original contribution to knowledge' (Higher Education Authority, 2017: Principle 1). The second principle goes further by suggesting that the 'successful completion and examination of the research thesis, comprising work of publishable quality, is the basis for the award of the doctoral degree. The thesis can be presented in a variety of formats' (Higher Education Authority, 2017: Principle 2). Two measurable indicators of meeting these principles include the use of external experts to examine the final thesis ${ }^{6}$ (Indicator O: Figure 1) and publications from the doctoral study (Indicator P: Figure 1). Publishing from the thesis increases students' career prospects and indicates that doctoral provision is high quality (Tsinidou et al., 2010).

\section{Data Collection}

We apply our framework in the context of accounting doctoral provision in HEIs in Ireland. We obtain information for each quality indicator using form-oriented coding of HEI websites and their prospectuses. Coding allows both quantitative and qualitative data to be assigned to predefined categories and analysed to identify patterns in the information reported (Guthrie, Petty, Yongvanick and Ricceri, 2004). We mostly use a simple dichotomous coding system. The only exception is the proportion of staff engaged in research activity, calculated as a percentage ratio. The analysis does not derive meaning from the information provided on websites or prospectuses, except to determine whether an indicator of quality is evident in the HEI. We include an appendix defining the coding of our sixteen quality indicators.

Coding takes a mechanistic approach in measuring quality. However, this approach ignores the views of students. To provide insights on the quality of provision, we ascertain the views of accounting doctoral students on the quality of doctoral education in HEIs in Ireland. We employ semi-structured interviews (the interview guide is available from the authors on request) with 36 accounting doctoral students to gain deeper insights (Denscombe, 2010) into some of the measurable indicators of quality included in our analytical framework. Interviews provide richer data than survey data (Saunders, Lewis and Thornhill, 2016). Of the 36 doctoral students involved in the study, 20 are full-time and 16 are parttime. All ten HEIs offering doctoral education in Ireland (see previous section) are represented in the sample. We conducted interviews over two days at the Irish Accounting and Finance Association conference and doctoral colloquium in 2016, at interviewees' HEIs and using Skype. Interviews lasted between 15 and 100 minutes. 
Ward et al.

Research ethical clearance was obtained, an information sheet distributed to each interviewee at the start of the interview and consent obtained before the interview proceeded. Interviews were transcribed. To reduce subjectivity, using the analytical framework shown in Figure 1, two individuals independently thematically coded the transcripts before discussing and agreeing the results (McCracken, McIvor, Treacy and Wall, 2017).

\section{RESULTS}

In this section, we discuss the results of our mechanistic assessment of quality doctoral education using our analytical framework. We consider the results under the four dimensions - context, inputs, processes and outcomes. We deepen our assessment with a discussion of interviewee perceptions of the quality dimensions in our analytical framework.

\section{Context (Mechanistic Evidence RQ1)}

Regarding our first dimension, context, we assess the research environment using four measurable indicators of quality. To capture staff engagement in research activity (Indicator A: Figure 1), we record the proportion of faculty in accounting departments with a doctoral qualification. ${ }^{7}$ We report the findings in Table 2. Our HEIs employ 120 accounting staff. Of these, 52 (43 per cent) hold a doctoral qualification. The proportion of doctoral qualified staff varies considerably. In one institution 78 per cent of accounting faculty have a doctorate, while in another 24 per cent are doctoral qualified. Thus, while there is availability of qualified research supervisors in HEIs in Ireland overall, some HEIs are better capacitated than others.

TABLE 2: PROFILE OF ACCOUNTING FACULTY IN HEIS IN IRELAND THAT PROVIDE DOCTORAL EDUCATION AS OF APRIL 2018

\begin{tabular}{lccc}
\hline HEI (No.) & $\begin{array}{c}\text { Accounting Faculty } \\
\text { No. }\end{array}$ & \multicolumn{2}{c}{ Doctoral Qualified } \\
& No. & $\%$ \\
\hline HEI I & 14 & 7 & 50 \\
HEI 2 & II & 3 & 27 \\
HEI 3 & 10 & 4 & 40 \\
HEI 4 & 9 & 7 & 78 \\
HEI 5 & 4 & 2 & 50 \\
HEI 6 & 11 & 6 & 55 \\
HEI 7 & 15 & 9 & 60 \\
HEI 8 & 10 & 4 & 40 \\
HEI 9 & 17 & 4 & 24 \\
HEI I0 & 19 & 6 & 32 \\
Total & 120 & 52 & 43 \\
\hline
\end{tabular}


In terms of the extent of supervisory training in place (Indicator B: Figure 1), we find that three of the ten institutions require supervisors who have no experience of supervising to completion to attend courses on supervision. This low requirement is surprising given the strong encouragement for supervisory experience in the literature (Hammond et al., 2010; Kiley, 2011) and in the NFDE (Higher Education Authority, 2017). However, generally supervisors are required to have supervisory experience (see our discussion in the inputs section). Five of the ten HEIs disclose that they have a specific faculty or HEI-wide doctoral college (Indicator C: Figure 1) and eight provide opportunities to network with relevant peers (Indicator D: Figure 1). The Salzburg recommendations (European University Association, 2005, 2010) stress the centrality of an inclusive research environment to a critical mass of research in HEIs. Therefore, our findings suggest that the quality of doctoral education in accounting in some HEIs is below par with respect to the environment in which students work.

\section{Context (Humanistic Evidence RQ2)}

We obtained deeper insights into the research environment from the semi-structured interviews. We report the main findings in Table 3 and provide quotations to highlight themes that emerged. We analyse our findings by mode of study, as HEIs typically have different requirements for part-time and full-time students. When asked about research culture, 10 of the 36 interviewees identified that their HEIs have a strong research culture and seven others commented on internal workshops and internal seminars in response to this question, though some note that these events are not accounting related.

TABLE 3: INTERVIEW FINDINGS FOR RESEARCH CULTURE (INDICATOR C) AND NETWORK OPPORTUNITIES (INDICATOR D)

\begin{tabular}{lccc}
\hline & \multicolumn{2}{c}{ Mode of Study } & \\
& Part-Time No. & Full-Time No. & Total No. \\
\hline Culture & 5 & 5 & 10 \\
Supportive & 4 & 3 & 7 \\
Workshops/seminars & 7 & 12 & 19 \\
Poor & 16 & 20 & 36 \\
Total & & & \\
& & & 17 \\
Networks & 5 & 12 & 11 \\
Strong & 7 & 4 & 8 \\
Some opportunities & 4 & 4 & 36 \\
Poor & 16 & 20 & \\
Total & & & \\
\hline
\end{tabular}

In Quotation 1, one faculty member, studying for a doctorate part-time and working in the HEI, comments on the conflict between non-research-active staff and 
Ward et al.

research-active staff and the lack of recognition by managers that research is part of the role of a lecturer in their department.

Quotation 1: Research-active versus non-research-active staff

It's a concern. There are a lot of anti-research people with the 'they do nothing and blah blah blah' attitude that is out there .... It's a concern because it's not true. It's very difficult to do and it's not sustainable. That's the point. You can say I'm doing it because I hope that when I get to the end of it that I will get hours off my timetable and I will be able to continue my research. But if I don't, we'll just ditch the research. That's what an awful lot of my colleagues' attitudes are. So, unless they get time off, they're just going to stop.

Faculty members studying part-time echo this type of conflict. In general, they feel that their managers do not understand the amount of time required to undertake research; managers think that teaching is the most important part of a lecturer's role. Furthermore, three part-time students say their HEIs cater for full-time but not part-time doctoral students. When asked about research networks, seventeen say they are supported in developing research networks, whereas eight say their HEI does not support/fund research networking. Networking opportunities are believed to offer both a source of knowledge and support to students (Amundsen and McAlpine, 2009; Sweitzer, 2009; McAlpine and Amundsen, 2012). However, interviewee perceptions on the usefulness of networking are mixed. For example, two part-time students say that conferences are a waste of time, with one commenting that seminars or presenting work at workshops is more beneficial (Quotation 2).

Quotation 2: Benefit of research networking

I find those informal ones [workshops] more useful than going to conferences because it gets you to ... you present your stuff, which I think is worthwhile, trying to articulate it. But I have not found going to conferences useful from the point of view of progressing with the PhD, given how much limited time I have. I just don't see the point in going to them. I really don't. Seminars like that, I think are useful. It's more intimate. You're meeting other PhD students. It's quite useful but just a few.

Full-time interviewees are more positive about the benefits of attending conferences, so it seems that time constraints influence students' ability to network. A full-time student (Quotation 3) identifies a variety of networking opportunities encouraged by the HEI, also noting the important role that social media plays in networking.

Quotation 3: Research networking opportunities

I do feel as if I have enough opportunities to network. Yes, definitely. There are conferences obviously as well. I'm not short of places to hear new information. I also use Twitter a lot. There are key authors that I follow on Twitter and that does certainly give you quick access to information. 
We also asked students if they are given the opportunity to network with other doctoral students within their institution. Again, different experiences are noted, with part-time students finding that while they have the potential, they do not have the time to get involved in networking:

Quotation 4: Time constraints on research networking

There are plenty of opportunities that I could be taking but it's just because of the time factor that I don't.

Other interviewees note that networking opportunities are available but questioned their relevance. Distance from institution is a common theme amongst part-time doctoral students, some of whom are enrolled in HEIs that do not have a strong research culture. Rearranging teaching and factoring in travel time means that attending research network events is difficult for accounting faculty enrolled part-time.

Quotation 5: Lack of networking opportunities in HEIs lacking research culture

In X [the HEI registered at], not really no and I wouldn't anticipate that I would have much interaction with them because of the geographical distance. Again, that's why it would be better if there were a more structured formal community in the institution $[Y]$ that I work in. I'm not really availing of it in $X$ and I'm missing out on those opportunities.

Lack of a critical mass of accounting doctoral students is another common theme. Whilst most of the interviewees had some interest in connecting with doctoral students from other disciplines, most craved interaction with accounting doctoral students:

Quotation 6: Lack of opportunities to interact with fellow doctoral students

Where I am now, there is just one other person who is in accounting - most of them are in finance. I feel I cannot share my stuff [specialist knowledge] with them. Well, I can but they are not in my group.

To conclude, interviewees working in HEIs report negative impact on their doctoral studies from a lack of understanding of their situation by non-research-active colleagues and management. Interviewees also find the trade-off between networking and progressing their thesis challenging.

\section{Inputs (Mechanistic Evidence RQ1)}

The second dimension of our study concerns inputs. Half of the HEIs explicitly require a research proposal (Indicator E: Figure 1), with the remaining HEIs referring to some form of initial review involving an initial report and/or attendance at an initial meeting or formal review in the early stages of the doctoral programme. The second input indicator of quality in our analytical framework considers the 
Ward et al.

mechanisms in HEIs to ensure appropriate supervision (Indicator F: Figure 1). Whilst not requiring a track record of successful doctoral completion, one institution requires supervisors to have prior supervision experience or to have completed a research supervision training programme. The other nine HEIs report that lead supervisors must have a track record of successful doctoral completion or have a second supervisor with such experience. A second supervisor is also typically required where the lead supervisor is not a member of staff, where the lead supervisor does not have a doctorate or where the research is interdisciplinary. An advisor may be involved in supervision in some institutions. The advisor typically does not get involved in the day-to-day supervision but provides expert guidance when required. This is most common when the research is interdisciplinary. Thus, HEIs seek supervision by faculty members with research and/or supervision experience. Furthermore, the references to interdisciplinary arrangements suggest that HEIs ensure the needs of students undertaking interdisciplinary research are catered for. All HEIs mention that doctoral students have access to facilities, including the library.

In terms of established structures, HEIs emphasise attending courses and collecting credits, particularly in the first two years. All ten HEIs require doctoral students to attend taught courses, with nine making this condition compulsory before students can progress. Six institutions detail courses on offer (Indicators H and I: Figure 1). While not addressing a research question per se, we nonetheless list the courses in Table 4 in order of prevalence as we believe such as list would be of interest to readers. The remaining four HEIs do not provide such detail, referring to a central department either within the HEI or between HEIs that provided the courses. ${ }^{8}$

TABLE 4: COURSES ON OFFER IN ACCOUNTING DOCTORAL PROGRAMMES IN HEIS IN IRELAND

\begin{tabular}{ll}
\hline \multicolumn{1}{c}{ Topic Areas } & \multicolumn{1}{c}{ Topic Areas } \\
\hline Stipulated on 5-6 websites & Stipulated on I-2 websites \\
Research methods & Working with your supervisor \\
Academic writing & Commercialisation \\
Ethics & Forming a research project \\
Project management & Intellectual property \\
Digital skills/data & Writing papers/getting published \\
Communication/outreach/presentations & Poster design \\
Statistics/analysing data & Selecting conferences, presenting and networking \\
& Editing skills \\
& Thesis completion \\
Stipulated on 3-4 websites & Cloud computing \\
Literature review & PhD internship \\
Teaching and learning/career & Conference organisation \\
Creation and innovation & Research placement/work placement \\
\hline
\end{tabular}


TABLE 4: (CONTINUED)

\begin{tabular}{ll}
\hline \multicolumn{1}{c}{ Topic Areas } & \multicolumn{1}{c}{ Topic Areas } \\
\hline Philosophy of social sciences & Critical thinking \\
Viva preparation & Time management \\
Transfer preparation & Stress management \\
& Research planning \\
& Data management \\
& Theoretical paradigms \\
\hline
\end{tabular}

It is noteworthy that all courses described on websites are generic, though some identify discipline-specific courses, but no detail is provided. Implementation of the Irish Universities Association's (2015) recommendations is evident. Most HEIs offer courses covering the areas required under the IUA's (2015) educational objectives. HEIs have agreed that students from any other HEI can attend courses on offer. Hence, courses are available to all students irrespective of their HEI. ${ }^{9}$

\section{Inputs (Humanistic Evidence RQ2)}

We obtained further detail on the inputs directly affecting doctoral students (Indicators G, H and I: Figure 1) from semi-structured interviews. Students confirmed that HEIs invest in workspaces and provide library access and sufficient quiet space for students (Table 5). All full-time students stated that they had library access, while sixteen ( 80 per cent) have dedicated desks and quiet space (Indicator G: Figure 1). Although most part-time students have library access (13 or 81 per cent), relative to their full-time peers, they are not as well accommodated in terms of workspace or access to a quiet space. Four part-time students have a desk and six (38 per cent) have enough quiet space. IT does not appear to pose a problem, with only three $(8$ per cent) interviewees reporting IT problems.

TABLE 5: INTERVIEW FINDINGS ON RESOURCES PROVIDED

\begin{tabular}{lccc}
\hline & \multicolumn{2}{c}{ Mode of Study } & \\
& Part-Time No. & Full-Time No. & Total No. \\
\hline Resource provided & 16 & 20 & 36 \\
Individual desk & 4 & 16 & 20 \\
Library & 13 & 20 & 33 \\
Quiet space - yes & 6 & 16 & 22 \\
IT problems & - & 3 & 3 \\
\hline
\end{tabular}

To determine perspectives on courses (Indicators H and I: Figure 1), we asked interviewees 'Does the institution provide the support you expected, in terms of training for example?' When an interviewee does not elaborate sufficiently, follow-up questions probe whether the interviewee believes the number of courses, the course content, and timing and location of courses are appropriate. Table 6 summarises the results, analysed by mode of study. 
Ward et al.

TABLE 6: STUDENT VIEWS ON COURSES PROVIDED BY HEIS IN IRELAND BY MODE OF STUDY

\begin{tabular}{lccc}
\hline & \multicolumn{2}{c}{ Mode of Study } & \\
& Part-Time No. & Full-Time No. & Total No. \\
\hline Relevance of courses & 5 & 2 & 7 \\
Courses - relevant & 4 & 5 & 9 \\
Courses - neither relevant nor not relevant & 7 & 13 & 20 \\
Courses - not relevant & 16 & 20 & 36 \\
Total & & & \\
Availability of courses & 12 & 18 & 30 \\
Courses - plentiful & 4 & 2 & 6 \\
Courses - insufficient & 16 & 20 & 36 \\
Total & & & \\
Timing of courses & 1 & 4 & 5 \\
Courses - timing problem & 15 & 16 & 31 \\
Courses - timing not a problem & 16 & 20 & 36 \\
Total & & & \\
\hline
\end{tabular}

Interview responses are varied. For example, in one instance a full-time doctoral student stated that courses are plentiful, though general. This student is one year into the programme and notes by this point no training relating to their specific needs had been received. This student is clearly engaged with their HEI, as they refer to 'we' when talking about course provision (Quotation 7).

\section{Quotation 7: Lack of specific training}

Well what we do here is a generic skills course that runs twice weekly during the semester. So, it's about three to four hours every week. I think they are pretty good and they do cover a lot of, not really just the work side of things, but the life balance as well. There's been no specific skill training for me thus far [one year in] but I guess that's more of an onus on me to pursue that.

In another instance (Quotation 8), a student had to pay for a course they needed to attend as the offering in the HEI did not cover their needs.

Quotation 8: Lack of funding for specific courses

The courses they offer are not enough. I think they could be more tailored. The courses that I took were very basic. I am very quantitative, so I need training in some programmes and I did it by myself and I had to pay for some courses by myself.

A student comments on the requirements within the HEI to collect credits by passing courses before they could graduate. They note that this causes dysfunctional 
behaviour resulting in doctoral students selecting courses based on credits and not on skills development or need.

Quotation 9: Collecting credits

Honestly, I was quite shocked at the level of support. [...] I didn't think that the level of research courses available was that good or are that good. There are a lot of courses that are not relevant at all and there are much more courses that could be there. For some of the courses, people are just going because within this institution you have to build up X credit points in terms of research training which is the equivalent of about two weeks' training per year. People are selecting courses with higher points to build up their points and they're not very relevant to them at all. I found a lot of the courses were very general. A lot of the useless ones were taking up a lot of time. The online ones totally weren't relevant to any discipline and were very general. I was shocked at that and a lot of other PhD students who I've met on these courses would say the same.

A part-time student, also a staff member, comments on the conflict between time taken attending courses and doing their own research. When we asked whether the courses were necessary, the interviewee said there are too many non-relevant courses (Quotation 10).

Quotation 10: Trade-off between research training and own research

Particularly starting off doing the research modules which take up a huge amount of time, as opposed to actually doing any basic research.

Finally, though noting that courses are available, some part-time doctoral students and faculty members state that they cannot physically attend due to teaching requirements or distance to the HEI hosting the course. Views of doctoral students in our study reflect Borthwick and Wissler's (2003) findings that students in Australia welcome professional and personal skills training courses. However, Borthwick and Wissler (2003) also note students' concerns about HEIs taking generalised approaches which do not accommodate their specific requirements and overlooking the problems students face in meeting the demands for generic research capabilities, alongside the research project and thesis, in the limited time available in their doctoral programme. Similarly, in their UK study, Johnston and Murray (2004) note that whilst students perceive benefit from generic skills training, they feel it could be improved by being tailored to students' discipline.

\section{Processes (Mechanistic Evidence RQ1)}

The third dimension to our study examines processes. All institutions provide a dedicated supervisor (Indicator J: Figure 1). In general, two supervisors are required - a lead supervisor and one other. However, four HEIs allow one supervisor and one HEI requires three or more where students' theses span more than one topic area. Nine of the ten HEIs require the lead supervisor to be from the HEI. 
Ward et al.

There is evidence of variation at the start of the doctoral programmes across the HEIs. For example, only five of the ten refer to induction and this is predominantly in the context of full-time provision. That is not to say induction does not happen. It is just not mentioned on websites or in prospectuses. In terms of periodic review and progress milestones (Indicator K: Figure 1), eight of the ten HEIs refer to some form of initial review that requires students to prepare an initial report (three HEIs), or to attend an initial meeting (three HEIs), or to undertake a formal initial review that involves preparing a report and presenting their work to a research panel (two HEIs). The remaining two institutions do not mention any initial review in their documentation or on their website. Finally, one HEI requires its doctoral students to present at its internal seminar series on a yearly basis. This practice is noted in other HEIs' documentation but is not referred to as compulsory.

Table 7 summarises the progress milestones in the ten HEIs which are broadly similar (Indicators K and L: Figure 1). In all instances, students must register, attend annual reviews, undertake a form of transfer ${ }^{10}$ from a postgraduate research programme to the doctorate, ${ }^{11}$ submit a soft copy of their thesis, defend their thesis in a viva voce, undertake revisions (if required) and submit a hard copy of their thesis to graduate. In nine of the ten HEIs, an external progress panel or head of research acts as a quality control, reviewing doctoral student work at inception, periodically and at major milestones (Indicators $\mathrm{M}$ and $\mathrm{N}$ : Figure 1). We find some variation in the extent and timing of these independent reviews and differences in terms of composition of the panel. For example, in one instance, the panel also includes the supervisors, whereas another two interviewees state that supervisors are excluded from the panel.

TABLE 7: MILESTONES IN DOCTORAL EDUCATION IN ACCOUNTING IN HEIS IN IRELAND

\begin{tabular}{lc}
\hline \multicolumn{1}{c}{ Progress Milestones } & HEIs (No.) \\
\hline Induction & 5 \\
& 3 \\
Initial plan report & 3 \\
Initial formal meeting & 2 \\
Initial formal review & \\
& 10 \\
Registration & 10 \\
Annual reviews & 10 \\
Transfer/differentiation/confirmation & 10 \\
Submission of thesis - soft copy & 10 \\
Viva voce & 10 \\
Revisions & 10 \\
Submission of thesis - hard copy & \\
Progress panel & 8 \\
HEl head of research & 1 \\
\hline
\end{tabular}




\section{Processes (Humanistic Evidence RQ2)}

When asked about induction, only one part-time doctoral student referred to lack of induction in Quotation 11.

\section{Quotation 11: Induction}

There was no induction, nothing. It was sort of that you had to find your way in the dark a bit.

In general, this student did not feel supported by the HEI and the lack of induction contributed to this perception. We asked interviewees about their periodic reviews/ progress milestones and whether they find them useful. There were eighteen interviewees who consider the reviews to be beneficial, consistent with the literature which indicates that regular progress reviews contribute to doctoral candidates' likely completion (McAlpine and Norton, 2006). However, two interviewees considered progress reviews as a negative experience, with the remaining interviewees having no strong views. In terms of positives, interviewees said that they used the reviews as a road map, a target to work towards. They comment that presenting to an independent panel is a useful check on their work and several note the benefits they obtained from feedback received (e.g. Quotation 12).

\section{Quotation 12: Benefits of periodic reviews/progress milestones}

Six-monthly [frequency]. Yes, I do find them useful. Number one, it stimulates me to feel pressurised to have progress made and it really makes me focus my thoughts on where I am. Number two, there are very helpful, practical suggestions from it. It is a diversity of views from the panel. ... I haven't gotten formal reports back from my panel on the last two occasions, but I think that's just because the chair of the panel has a completely busy job. But X [supervisor] would feed back so I'm happy with that.

Consistent with the latter comment, in some instances, while reviews occur, students are not receiving feedback or timely feedback. In Quotation 13, one interviewee comments on being subjected to over two hours of questions at their confirmation review, yet after the review, no one informed the student of the outcome. After a period of time, the interviewee just assumed that the review must have been successful.

\section{Quotation 13: Lack of feedback following milestone/review}

It's [the confirmation report] sent to London [to the external examiner, ' $X^{\prime}$ ] and $X^{\prime}$ s on Skype but even at the end of it, I presented for 25 minutes and X questioned me for two hours and ten minutes. Even at the end of that you still don't know. The only result is confirm or non-confirm and you still don't know, did I get confirmed or not?

Another interviewee, who is positive about the benefits of formal reviews, notes that policy in their HEI is to have two formal reviews only, with none after eighteen months. The interviewee considers this to be a missed opportunity (Quotation 14). 
Ward et al.

Quotation 14: Insufficient periodic review/progress milestones

After eighteen months, we have a confirmation of whether you are qualified to continue or not and then after that nothing else.

In Quotation 15, one part-time doctoral student states that their formal reviews are just window-dressing as they do not involve independent panel members, just the supervisor with a form.

Quotation 15: Lack of substantive periodic review/progress milestones

Because I only have one panel member, it was essentially just a meeting with my supervisor.

Finally, two part-time students registered at the same HEI said the review process is poor, that their panels are good at telling them that their work is not very good and make suggestions that are totally inconsistent with their topic. In one instance (Quotation 16), an interviewee commented that the panel members are not suitable for their panel as their area of expertise and interest is totally different to the student's:

\section{Quotation 16: Overly critical and inappropriate feedback}

No, I didn't find it useful. I found it immensely frustrating. It was just dreadful. ... My doctoral panel group were all quantitative researchers involved in game theory and all that type of thing, which had no relevance to what I was doing and they just couldn't see beyond a quantitative approach. I found that really frustrating.

Content analysis of the websites and prospectuses identifies that HEIs offer a wide range of courses and have appropriate milestones and processes in place. The only exception is induction. In addition, deeper insights from students suggest a 'tick box' exercise. Some interviewees noted that they do not have access to a quiet space, several interviewees commented that course provision is not sufficiently tailored, and a small number perceived that the progress panel did not have relevant expertise.

\section{Outcomes (Mechanistic Evidence RQ1)}

We use two measures to indicate outcome quality: the use of topic experts in the examination process and publications from the study. All ten HEIs use experts to examine the final thesis (Indicator O: Figure 1). Finally, publications from the thesis confirm contribution to the prior literature and the thesis being of publishable quality (Indicator P: Figure 1). Table 8 identifies that 39 per cent of the sample (14 out of 36) have published by 2019. This output is an objective measure of the quality of their research experience.

At the interview stage in 2016 seven interviewees indicated that they had published (Interviewees 1-7: Table 8). Of these, three had published in peer-reviewed outlets only (Interviewees 1, 4 and 5: Table 8), two published in both peer-reviewed 
TABLE 8: INTERVIEWEE PUBLICATIONS 2016-2019

\begin{tabular}{lcccccc}
\hline $\begin{array}{l}\text { Interviewee } \\
\text { Number }\end{array}$ & 2016 & 2017-2019 & $\begin{array}{c}\text { Total } \\
\text { 2016-2019 }\end{array}$ & 2016 & 2017-2019 & $\begin{array}{c}\text { Total } \\
\text { 2016-2019 }\end{array}$ \\
\hline I & 1 & 0 & 1 & 0 & 0 & 0 \\
2 & 0 & 0 & 0 & 2 & 6 & 8 \\
3 & 1 & 2 & 3 & 5 & 2 & 7 \\
4 & 2 & 2 & 4 & 0 & 0 & 0 \\
5 & 1 & 5 & 6 & 0 & 1 & 1 \\
6 & 0 & 0 & 0 & 5 & 0 & 5 \\
7 & 1 & 0 & 1 & 2 & 0 & 2 \\
8 & 0 & 1 & 1 & 0 & 1 & 1 \\
9 & 0 & 1 & 1 & 0 & 0 & 0 \\
10 & 0 & 0 & 0 & 0 & 1 & 1 \\
11 & 0 & 0 & 0 & 0 & 1 & 1 \\
12 & 0 & 1 & 1 & 0 & 0 & 0 \\
13 & 0 & 0 & 0 & 0 & 2 & 2 \\
14 & 0 & 2 & 2 & 0 & 0 & 0 \\
Total & 6 & 14 & 20 & 14 & 14 & 28 \\
\hline
\end{tabular}

and scholarly outlets (Interviewees 3 and 7: Table 8) and two in scholarly outlets only (Interviewees 3 and 6: Table 8). The seven doctoral students published twenty outputs between them. After examining each of the interviewees' profiles, we extended the table to include outputs between the date of the interviews and the time of writing this paper, February 2019. In total, interviewees published a further fourteen peer-reviewed articles and fourteen scholarly outputs, bringing the total published outputs for the sample to 48. By 2019 a further seven of the original interviewees had started to publish. Three of these published in peer-reviewed outlets only (Interviewees 9, 12 and 14: Table 8), one published in a peer-reviewed and a scholarly outlet (Interviewee 8: Table 8) and three published in scholarly outlets only (Interviewees 10, 11 and 13: Table 8). Further, four of the interviewees who had published at the time of their interview had continued to publish (Interviewees 2, 3,4 and 5: Table 8). Finally, this profile analysis revealed that seven of the 36 interviewees had successfully obtained their doctorate.

\section{Outcomes (Humanistic Evidence RQ2)}

We asked interviewees their opinion on publishing from their thesis. It was clear from the responses that supervisors take different approaches to publication, even within the same HEI. For example, one student who had not published from the research, when asked if the supervisor encouraged them to publish, said (Quotation 17):

Quotation 17: Publishing from the doctoral research 
Ward et al.

Yes, they do [encourage]. I think it's a great idea because if I get to the viva and I have a published paper then my work is already peer-reviewed so that'll stand to me so .... Yeah, they're very encouraging.

Another interviewee felt disadvantaged by not having the opportunity to publish (Quotation 18). The interviewee expanded by saying how important it is to have publications when applying for an academic post, that the doctoral qualification did not carry as much weight as a publication.

Quotation 18: Publishing from the doctoral research

No. There was a definite discouragement to publish during the PhD. I was not happy with this approach.

In another instance (Quotation 19), it was clear that the supervisor had a flexible approach to publishing from the thesis. This supervisor obviously felt that encouraging the interviewee to publish would be detrimental to their health and to the timely completion of the thesis.

Quotation 19: Publishing from the doctoral research

No. We've discussed this and because I'm behind on my schedule and we don't know what the future holds in that there are no guarantees with my health. She said she wouldn't want to put any pressure on me to publish because that means I could make myself ill and set myself back if I was working on publishing and delayed researching and took unwell. I have to get the balance right; it's a bit difficult for me so it's not really a priority.

Whilst the data collected in Table 8 identifies that 39 per cent of the sample have published, it is clear from the interviews that there is variation in the stance supervisors take to publishing during the doctoral programme. Some students are actively discouraged from publishing, others are encouraged. In addition, our data collection does not capture work in progress. It can take a long period to get an article accepted in a peer-reviewed journal. Therefore, further analysis over time would lead to more reliable information on outputs.

We draw together and discuss the implications of our results in the next section.

\section{CONCLUSION}

We investigated the quality of doctoral education in accounting in HEIs in Ireland using both a mechanistic and a humanistic approach. The mechanistic approach involved developing an analytical framework for measuring quality doctoral education and applying this framework in the context of HEIs in Ireland. To add insights to the findings of the mechanistic approach, we adopted a humanistic approach involving semi-structured interviews with 36 doctoral students. 
In general, when we analysed doctoral provision on offer in HEIs in Ireland we found that accounting doctoral education is widely available, standardised and consistent with the four dimensions of quality doctoral education in our analytical framework. Induction was the only area that was not widely included in information on doctoral courses when we examined websites and prospectuses. This suggests a quality doctoral education system for accounting in Ireland. However, we highlight one area of concern - the research environment dimension, in particular the proportion of research-active staff as this affects the other research environment indicators. The low proportion of research-qualified accounting faculty led us to examine the profile of faculty in accounting departments. Relative to other disciplines, there is a lack of accounting professors and associate professors/senior lecturers in several HEIs in Ireland. This raises questions about the historic investment in research culture in accounting departments. Without senior role models to guide and motivate, we question how a supportive and fruitful research environment can be cultivated. This issue appears particularly acute in the Republic of Ireland, where only 18 per cent of accounting faculty are at either professor or senior lecturer grade. Indeed, this overarching statistic masks underlying variation, with some institutions having no senior accounting faculty. In Northern Ireland, 26 per cent of faculty have progressed to professor or senior lecturer level. This higher level may be a consequence of institutions in Northern Ireland being subject to assessment under the UK Research Excellence Framework (REF). This framework is used to allocate research funding to HEIs (Stern, 2016). Perhaps this focuses the minds of university managers in UK HEIs on research. The deficit of senior faculty, especially in the Republic of Ireland, will be difficult to overcome as a lack of accounting professors in many HEIs makes it difficult to negotiate resources and other changes required to promote an inclusive research environment within accounting departments. As such, an all-Ireland approach might be a solution, for example, whereby the Irish Accounting and Finance Association champions the need for accounting departments to be adequately resourced with suitably qualified senior professors, with supports and incentives for research at all levels.

As predicted, more nuanced aspects of quality doctoral education became evident when we considered student perceptions of their experiences of doctoral education in accounting. For example, though HEI websites and prospectuses identified a wide range of courses on offer, interviewees identify shortcomings with course provision, in terms of relevant content and timing. Therefore, doctoral providers should consider whether their course provision requires some tailoring to suit the specific needs of disciplines, such as accounting. Furthermore, in terms of the practicalities of providing training, the approach currently taken may require adjustment to accommodate the needs of part-time students, who are often remote users of their institutions' facilities, perhaps through greater use of online courses, remote attendance (for example using Skype), workshops, weekend workshops or closer network links between HEIs, so part-time students can attend HEIs that are geographically closer. Though interviewees consider progress milestones to have a positive role in quality doctoral education, interviewees also identified some issues in terms of feedback and number of milestones. Thus, while the relevant structures and quality assurance measures necessary for a good-quality doctoral process 
Ward et al.

are present in HEIs in a general sense, the need for fine-tuning of the approach is evident.

Our study has several limitations. First, we source compliance with the indicators of quality doctoral education under our analytical framework by coding HEI websites and prospectuses. It may be that HEIs do not include the relevant information in their website or prospectus. This is consistent with the findings of Brink, Glasscock and Wier (2012), who note that US HEI websites do not provide all the information about admission and programme requirements useful for potential students. Second, as we identified in the literature section, student views are subjective and need to be interpreted with care as they may not reflect the experience of other doctoral students in the same HEI. Whilst semi-structured interviews are designed to elicit students' view of the dimensions and indicators of quality doctoral education independently, interviewees may be influenced by their relationship with their supervisors, which may affect their perception of their HEI. Third, the second measure of outcome quality is publications from the thesis. Our research is constrained in fully assessing this data. We recommend a longitudinal study tracking each student in the period after completion to assess this metric properly. Fourth, we have not captured views of supervisors in this research. Fifth, academic commentary suggests that skills training modules and courses offered to doctoral students in accounting may need to include some technical elements, consistent with the requirements of the profession (Fogarty and Black, 2014; Smith and Urquhart, 2018). Such training may enhance doctoral researchers' understanding of contemporary and future practice and how it can be improved (Kaplan, 2011) and positively impact teaching effectiveness (Howieson, 2003). We did not consider whether a professional-orientated approach to doctoral education would be more relevant or beneficial for the accounting discipline. Sixth, our findings relate only to an Irish context and may not be representative of other jurisdictions.

Finally, Fogarty and Holder (2012, p. 373) note that 'any group that cannot adequately replenish its ranks with dedicated full-time initiates becomes seriously threatened by aging and retirements'. Given the low numbers of doctoral graduates in accounting in Ireland, this threat cannot be ignored by accounting departments of Irish HEIs. While not an outright solution, our findings and suggestions to improve doctoral education in accounting may serve to improve student satisfaction in respect of quality doctoral education and hopefully increase completion rates in the future.

\section{ACKNOWLEDGEMENTS}

We acknowledge helpful comments on earlier drafts of the paper from participants at the Irish Accounting and Finance Association Annual Conference 2018 and at an internal seminar series in Ulster University in October 2018. We also thank the two anonymous reviewers and the two editors for their constructive comments. 


\section{FUNDING}

This work was supported by the Chartered Accounting Ireland Educational Trust.

\section{APPENDIX: ILLUSTRATION OF CODING QUALITY MEASUREMENT INDICATORS (MECHANISTIC APPROACH)}

\begin{tabular}{|c|c|c|}
\hline \multicolumn{2}{|r|}{ Quality Measurement Indicator } & \multirow{2}{*}{$\begin{array}{l}\text { Source of Data - Coding } \\
\text { Websites: Percentage of doctoral qualified staff within } \\
\text { the accounting department }(\%)\end{array}$} \\
\hline A. & $\begin{array}{l}\text { Proportion of staff engaged in } \\
\text { research activity }\end{array}$ & \\
\hline B. & Adequate training for supervisors & $\begin{array}{l}\text { Websites/prospectus - courses and/or mentoring by a } \\
\text { more experienced supervisor: coded I when evident, } \\
0 \text { otherwise }\end{array}$ \\
\hline C. & $\begin{array}{l}\text { Doctoral research centre with } \\
\text { international links }\end{array}$ & $\begin{array}{l}\text { Websites/prospectus: coded I when evident, } \\
0 \text { otherwise }\end{array}$ \\
\hline D. & $\begin{array}{l}\text { Opportunities to network with } \\
\text { relevant peers }\end{array}$ & $\begin{array}{l}\text { Websites/prospectus - doctoral workshops, seminar } \\
\text { series and doctoral colloquia: coded I when evident, } \\
0 \text { otherwise }\end{array}$ \\
\hline E. & Research proposal required & $\begin{array}{l}\text { Websites/prospectus: coded I when evident, } \\
0 \text { otherwise }\end{array}$ \\
\hline F. & $\begin{array}{l}\text { Quality control over supervisor } \\
\text { selection }\end{array}$ & $\begin{array}{l}\text { Websites/prospectus: coded I when evident, } \\
0 \text { otherwise }\end{array}$ \\
\hline G. & $\begin{array}{l}\text { Facilities - work area, information } \\
\text { technology (IT) and library }\end{array}$ & $\begin{array}{l}\text { Websites/prospectus: coded I when evident, } \\
0 \text { otherwise }\end{array}$ \\
\hline $\mathrm{H}$. & $\begin{array}{l}\text { Specific courses tailored to the } \\
\text { discipline }\end{array}$ & $\begin{array}{l}\text { Websites/prospectus: coded I when evident, } \\
0 \text { otherwise }\end{array}$ \\
\hline I. & $\begin{array}{l}\text { Training on general and specific } \\
\text { research methodology and } \\
\text { personal and professional } \\
\text { development }\end{array}$ & $\begin{array}{l}\text { Websites/prospectus: coded I when evident, } \\
0 \text { otherwise }\end{array}$ \\
\hline J. & $\begin{array}{l}\text { One-to-one supervision with a } \\
\text { topic expert }\end{array}$ & $\begin{array}{l}\text { Websites/prospectus: coded I when evident, } \\
0 \text { otherwise }\end{array}$ \\
\hline K. & $\begin{array}{l}\text { Periodic review and progress } \\
\text { milestones }\end{array}$ & $\begin{array}{l}\text { Websites/prospectus: coded I when evident, } \\
0 \text { otherwise }\end{array}$ \\
\hline L. & Defined procedure for qualification & $\begin{array}{l}\text { Websites/prospectus: coded I when evident, } \\
0 \text { otherwise }\end{array}$ \\
\hline M. & $\begin{array}{l}\text { An internal doctoral review panel } \\
\text { including external experts }\end{array}$ & $\begin{array}{l}\text { Websites/prospectus: coded I when evident, } \\
0 \text { otherwise }\end{array}$ \\
\hline N. & $\begin{array}{l}\text { A doctoral director - an expert } \\
\text { focal point for communication on } \\
\text { doctoral education }\end{array}$ & $\begin{array}{l}\text { Websites/prospectus: coded I when evident, } \\
0 \text { otherwise }\end{array}$ \\
\hline O. & $\begin{array}{l}\text { Use of external experts to examine } \\
\text { the final thesis }\end{array}$ & $\begin{array}{l}\text { Websites/prospectus: coded I when evident, } \\
0 \text { otherwise }\end{array}$ \\
\hline P. & Publications from the study & Websites/survey: coded I when evident, 0 otherwise \\
\hline
\end{tabular}


Ward et al.

\section{REFERENCES}

Amundsen, C. and McAlpine, L. (2009). Learning Supervision: Trial by Fire, Innovations in Education and Teaching International, Vol. 46, No. 3, pp. 331-342.

Beattie, V. and Smith, S.J. (2012). Today's Ph.D. Students - Is there a Future Generation of Accounting Academics or Are They a Dying Breed? A UK Perspective, Edinburgh: Institute of Chartered Accountants of Scotland.

Behn, B.K., Carnes, G.A., Krull Jr, G.W., Stocks, K.D. and Reckers, P.M. (2008). Accounting Doctoral Education - 2007. A Report of the Joint AAA/APLG/FSA Doctoral Education Committee, Issues in Accounting Education, Vol. 23, No. 3, pp. 357-367.

Benito, M. and Romera, R. (2013). How to Boost the PhD Labour Market? Facts from the PhD System Wide, Working Paper 13-28 Statistics and Econometrics Series 024 [online], available from: http:/ /e-archivo.uc3m.es/bitstream/handle/10016/17545/ws132824.pdf ?sequence $=1$, accessed 30 June 2018

Bolli, T., Agasisti, T. and Johnes, G. (2015). The Impact of Institutional Student Support on Graduation Rates in US Ph.D. Programmes, Education Economics, Vol. 23, No. 4, pp. 396-418.

Borthwick, J. and Wissler, R. (2003). Postgraduate Research Students and Generic Capabilities: Online Directions, Canberra, ACT: Department of Education, Science and Training.

Boyle, D.M., Carpenter, B.W., Hermanson, D.R. and Mensah, M.O. (2013). The Accounting Doctorate Shortage: Opportunities for Practitioners, Strategic Finance, Vol. 94, No. 11, pp. 31-36.

Brink, A., Glasscock, R. and Wier, B. (2012). The Current State of Accounting PhD Programs in the United States, Issues in Accounting Education, Vol. 27, No. 4, pp. 917-942.

Bruggen, E., Fouberr, B. and Gremler, D. (2011). Extreme Makeover: Short- and Long-Term Effects of a Remodelled Landscape, Journal of Marketing, Vol. 75, No. 5, pp. 71-87.

Chaubey, M. and Krivacek, G. (2016). Measures of Quality in Higher Education, Allied Academies International Conference, Academy of Educational Leadership. Proceedings, Vol. 21, No. 1, pp. $4-7$.

Chen, C.Y., Chen, P.C. and Chen, P.Y. (2014). Teaching Quality in Higher Education: An Introductory Review on a Process-Oriented Teaching-Quality Model, Total Quality Management and Business Excellence, Vol. 25, No. 1-2, pp. 36-56.

Cheng, M. (2011). 'Transforming the Learner' versus 'Passing the Exam': Understanding the Gap between Academic and Student Definitions of Teaching Quality, Quality in Higher Education, Vol. 17, No. 1, pp. 3-17.

Cheng, M. (2014). Quality as Transformation: Educational Metamorphosis, Quality in Higher Education, Vol. 20, No. 3, pp. 272-289.

Cheng, M., Taylor, J., Williams, J. and Tong, K. (2016). Student Satisfaction and Perceptions of Quality: Testing the Linkages for PhD Students, Higher Education Research and Development, Vol. 35, No. 6, pp. 1153-1166.

Collini, S. (2012). What Are Universities For?, London: Penguin.

de Valero, Y.F. (2001). Departmental Factors Affecting Time-to-Degree and Completion Rates of Doctoral Students at One Land-Grant Research Institution, Journal of Higher Education, Vol. 72, No. 3, pp. 341-367.

Denscombe, M. (2010) The Good Research Guide: For Small-Scale Research Projects, third edition, Maidenhead: Open University Press.

Department of Education and Skills (2011). National Strategy for Higher Education to 2030: Report of the Strategy Group [online], available from: http://hea.ie/assets/ uploads/2017/06/National-Strategy-for-Higher-Education-2030.pdf, accessed 3 July 2018. 
Douglas, J.A., Douglas, A., McClelland, R.J. and Davies, J. (2014). Understanding Student Satisfaction and Dissatisfaction: An Interpretative Study in the UK Higher Education Context, Studies in Higher Education, Vol. 39, No. 1, pp. 1-21.

Eccles, J.S. and Wigfield, A. (2002). Motivational Beliefs, Values, and Goals, Annual Review of Psychology, Vol. 53, No. 1, pp. 109-132.

Elliott, R.K. and Jacobson, P.D. (2002). The Evolution of the Knowledge Professional, Accounting Horizons, Vol. 16, No. 1, pp. 69-80.

European Commission (2011). Principles for Innovative Doctoral Training, Brussels: European Commission

European University Association (2005). Doctoral Programmes for the European Knowledge Society: Report on the EUA Doctoral Programmes Project [online], available from: https:/ / eua.eu/downloads/publications / doctoral \% 20programmes $\% 20$ for $\% 20$ the $\% 20$ european $\% 20$ knowledge $\% 20$ society $\% 20$ results $\% 20$ of $\% 20$ eua $\% 20$ doctoral $\% 20$ programme.pdf, accessed 13 February 2020.

European University Association (2010). Salzburg II - Recommendations: European Universities' Achievements since 2005 in Implementing the Salzburg Principles [online], available from: http://www.eua.be/Libraries/publications-homepage-list/Salzburg_II_ Recommendations, accessed 9 July 2018.

Fogarty, T.J. and Black, W.H. (2014). Further Tales of the Schism: US Accounting Faculty and Practice Credentials, Journal of Accounting Education, Vol. 32, No. 3, pp. 223-237.

Fogarty, T.J. and Holder, A.D. (2012). Exploring Accounting Doctoral Program Decline: Variation and the Search for Antecedents, Issues in Accounting Education, Vol. 27, No. 2, pp. 373-397.

Fogarty, T.J. and Markarian, G. (2007). An Empirical Assessment of the Rise and Fall of Accounting as an Academic Discipline, Issues in Accounting Education, Vol. 22, No. 2, pp. 137-161.

Gibbons, S., Neumayer, E. and Perkins, R. (2013). Student Satisfaction, League Tables and University Applications: Evidence from Britain, Economics of Education, Vol. 48, pp. 148-164.

Giese, J. and Cote, J. (2000). Defining Customer Satisfaction, Academy of Marketing Science Review [online], available from: http://www.proserv.nu/b/Docs/Defining\%20Customer\%20Satisfaction.pdf, accessed 3 July 2018.

Guber, T., Fub, S., Voss, R. and Zikuda, M. (2010). Examining Student Satisfaction with Higher Education Services: Using a New Measurement Tool, International Journal of Public Sector Management, Vol. 23, No. 2, pp. 105-123.

Guthrie, J., Petty, R., Yongvanick, K. and Ricceri, F. (2004). Using Content Analysis as a Research Method to Enquire into Intellectual Capital Reporting, Journal of Intellectual Capital, Vol. 5, No. 2, pp. 282-293.

Hammond, J., Ryland, K., Tennant, M. and Boud, D. (2010). Building Research Supervision and Training across Australian Universities: Final Report. Sydney, NSW: University of Technology, Sydney.

Harvey, L. (2006). Impact of Quality Assurance: Overview of a Discussion between Representatives of External Quality Assurance Agencies, Quality in Higher Education, Vol. 12, No. 3, pp. 287-290.

Higher Education Authority (HEA) (2017). National Framework for Doctoral Education [online], available from: http://hea.ie/assets/uploads/2017/04/national_framework_for_doctoral_education_0.pdf, accessed 29 June 2018.

Horta, H. and Santos, J.M. (2016). The Impact of Publishing during PhD Studies on Career Research Publication, Visibility, and Collaborations, Research in Higher Education, Vol. 57, No. 1, pp. 28-50. 
Ward et al.

Howieson, B. (2003). Accounting Practice in the New Millennium: Is Accounting Education Ready to Meet the Challenge? British Accounting Review, Vol. 35, No. 2, pp. 69-103.

Humphrey, R., Marshall, N. and Leonardo, L. (2012). The Impact of Research Training and Research Codes of Practice on Submission of Doctoral Degrees: An Exploratory Cohort Study, Higher Education Quarterly, Vol. 66, No. 1, pp. 47-64.

Irish Universities Association (IUA) (2015). PhD Graduate Skills Statement [online], available from: https://www.iua.ie/publications/iua-graduate-skills-statement-brochure-2015/, accessed 29 June 2018.

Irvine, H., Moerman, L. and Rudkin, K. (2010). A Green Drought: The Challenge of Mentoring for Australian Accounting Academics, Accounting Research Journal. Vol. 23, No. 2, pp. 146-171.

Ismail, A. Abdullah, M. and Francis, S. (2009). Exploring the Relationships among Service Quality Features: Perceived Value and Customer Satisfaction, Journal of Industrial Engineering and Management, Vol. 2, No. 1, pp. 230-250.

Johnston, B. and Murray, R. (2004). New Routes to the PhD: Cause for Concern?, Higher Education Quarterly, Vol. 58, No. 1, pp. 31-42.

Joseph, M., Yakhou, M. and Stone, G. (2005). An Educational Institution's Quest for Service Quality: Customers' Perspective, Quality Assurance in Education, Vol. 13, No. 1, pp. 66-82.

Kahu, E.R. (2013). Framing Student Engagement in Higher Education, Studies in Higher Education, Vol. 38, No. 5, pp. 758-773.

Kaplan, R.S. (2011). Accounting Scholarship that Advances Professional Knowledge and Practice, The Accounting Review, Vol. 86, No. 2, pp. 367-383.

Kiley, M. (2011). Developments in Research Supervisor Training: Causes and Responses. Studies in Higher Education, Vol. 36, No. 5, pp. 585-599.

Langstrand, J., Cronemyr, P. and Poksinska, B. (2015). Practise What You Preach: Quality of Education in Education on Quality, Total Quality Management, Vol. 26, Nos. 11-12, pp. 1202-1212.

Marzo-Navarro, M., Pedraja-Iglesias, M. and Rivera-Torres, M. (2005). Measuring Customer Satisfaction in Summer Courses, Quality Assurance in Education, Vol. 13, No. 1, pp. 53-65.

McAlpine, L. (2012). Identity-Trajectories: Doctoral Journeys from Past to Present to Future, Australian Universities Review, Vol. 54, No. 1, pp. 38-47.

McAlpine, L. and Amundsen, C. (2012). Challenging the Taken-for-Granted: How Research Analysis might Inform Pedagogical Practices and Institutional Policies Related to Doctoral Education, Studies in Higher Education, Vol. 37, No. 6, pp. 683-694.

McAlpine, L. and Norton, J. (2006). Reframing Our Approach to Doctoral Programs: An Integrative Framework for Action and Research, Higher Education Research E Development, Vol. 25, No. 1, pp. 3-17.

McCracken, M., McIvor, R., Treacy, R. and Wall, T. (2017). A Study of Human Capital Reporting in the United Kingdom, Accounting Forum, Vol. 42, No. 1, pp. 130-141.

Molesworth, M., Nixon, E. and Scullion, R. (2009). Having, Being and Higher Education: The Marketization of the University and the Transformation of the Student into Consumer, Teaching in Higher Education, Vol. 14, No. 3, pp. 277-287.

Morrison, E., Rudd, E., Zumeta, W. and Nerad, M. (2011). What Matters for Excellence in PhD Programs? Latent Constructs of Doctoral Program Quality Used by Early Career Social Scientists, Journal of Higher Education, Vol. 82, No. 5, pp. 535-563.

Nair, C., Murjocj, M. and Mertova, P. (2011). Benchmarking the Student Experience: The Offshore Campus Experience, The TQM Journal, Vol. 23, No. 6, pp. 585-597.

Nixon, M. and Scullion, R. (eds) (2010). The Marketisation of Higher Education and the Student as Consumer, London: Routledge 
O’Brien, C. (2018). Technological Universities a Step Closer Following Passage of Bill, Irish Times, 24 January 2018 [online], available from: https://www.irishtimes.com/news/ education/technological-universities-a-step-closer-following-passage-of-bill-1.3367279, accessed 27 June 2018.

Paisey, C. and Paisey, N.J. (2017). The Decline of the Professionally-Qualified Accounting Academic: Recruitment into the Accounting Academic Community, Accounting Forum, Vol. 14, No. 2, pp. 57-76.

Plumlee, R.D. and Reckers, P.M.J. (2014). Lessons Not Learned: Why Is there Still a CrisisLevel Shortage of Accounting PhDs?, Accounting Horizons, Vol. 28, No. 2, pp. 313-330.

Saunders, M., Lewis, P. and Thornhill, A. (2016). Research Methods for Business Studies, seventh edition, Harlow: Pearson Education.

Sinclair, J., Barnacle, R. and Cuthbert, D. (2014). How the Doctorate Contributes to the Formation of Active Researchers: What the Research Tells Us, Studies in Higher Education, Vol. 39, No. 10, pp. 1972-1986.

Smith, S.J. and Urquhart, V. (2018). Accounting and Finance in UK Universities: Academic Labour, Shortages and Strategies, British Accounting Review, Vol. 50, No. 6, pp. 588-601.

Stern, N. (2016). Building on Success and Learning from Experience: An Independent Review of the Research Excellence Framework [online], available from: https://assets.publishing.service. gov.uk/government/uploads/system/uploads/attachment_data/file/541338/ind-16-9ref-stern-review.pdf, accessed 9 July 2018.

Sum, V., McCaskey, S. and Kyeyune, C. (2010). A Survey Research of Satisfaction Levels of Graduate Students Enrolled in a Nationally Ranked Top-10 Program at a Mid-Western University, Research in Higher Education Journal, Vol. 7, No. 2, pp. 1-17.

Summers, J., Waigandt, A. and Whittaker, T. (2005). A Comparison of Student Achievement and Satisfaction in an Online versus a Traditional Face-to-Face Statistics Class, Innovative Higher Education, Vol. 29, No. 3, pp. 233-250.

Sweitzer, B. (2009). Towards a Theory of Doctoral Student Professional Identity Development: A Developmental Networks Approach, Journal of Higher Education, Vol. 80, No. 1, pp. 1-33.

Tsinidou, M., Georgiannis, V. and Fitsilis, P. (2010). Evaluation of Factors that Determine Quality in Higher Education: An Empirical Study, Quality Assurance in Education, Vol. 18, No. 3, pp. 227-244.

Turner, G. and McAlpine, L. (2011). Doctoral Experience as Researcher Preparation: Activities, Passion, Status, International Journal for Researcher Development, Vol. 2, No. 1, pp. 46-60.

Usher, R. (2002). A Diversity of Doctorates: Fitness for the Knowledge Economy?, Higher Education Research and Development, Vol. 21, No. 2, pp. 143-153.

Vauterin, J., Linnanen, L. and Marttila, E. (2011). Issues of Delivering Quality Customer Service in a Higher Education Environment, International Journal of Quality and Service Sciences, Vol. 3, No. 2, pp. 181-198.

Williams, J. (2013). Consuming Higher Education: Why Learning Can't be Bought, London: Bloomsbury.

Wisker, G., Robinson, G., Vernon, T., Creighton, E. and Warnes, M. (2003). Recognising and Overcoming Dissonance in Postgraduate Student Research, Studies in Higher Education, Vol. 28, No. 1, pp. 91-105.

Wittek, L. and Kvernbekk, T. (2011). On the Problems of Asking for a Definition of Quality in Education. Scandinavian Journal of Educational Research, Vol. 55, No. 6, pp. 671-684. 
Ward et al.

\section{END NOTES}

1 In this study, HEIs are universities, institutes of technology (Republic of Ireland) and colleges of further education (Northern Ireland).

2 The NFDE is a framework for quality doctoral education in Ireland (HEA, 2017). The most recent version was published after consultation with key stakeholders including the Irish Universities Association (IUA), the Institutes of Technology Ireland (IOTI), Quality and Qualifications Ireland (QQI), Irish Research Council (IRC) and the Irish government's Department of Jobs, Enterprise and Innovation.

3 The nine principles encapsulate the Salzburg principles (European University Association, 2005), the Salzburg II recommendations (European University Association, 2010) and the Principles for Innovative Doctoral Training (European Commission, 2011). A summary of the HEA's nine principles of quality doctoral education is as follows. Doctoral education:

1. involves deep engagement with a question, problem or hypothesis under supervision that makes an original contribution to knowledge;

2. requires the successful completion and examination of a research thesis, that comprises work of publishable quality;

3. increases significantly students' depth and breadth of knowledge of their discipline and develops expertise in research methodology;

4. is based in an institution with a sufficient critical mass of internationally recognised research activity;

5. is flexible:

6. is based in an institution where the research environment is of high academic quality including quality supervision;

7. prepares applicants and ensures qualified, competent and accessible supervision and resources are available;

8. has established supervision, progress-monitoring and examination processes; and

9. includes a robust quality assurance system.

4 We distinguish between doctoral 'programmes' and 'courses' offered on doctoral programmes.

See en 3 above.

This can also be considered a quality assurance metric.

There are limitations in using doctoral qualification as evidence of research activity, as some staff may have a doctorate but may not be research active. Likewise, other staff may be research active but are not doctoral qualified.

8 A list of topics on offer is not provided, as some HEIs do not provide any detail, referring to a central department either within the organisation or between organisations that provide the courses.

9 The Irish Universities Association (2015) PhD Graduate Skills Statement identifies key educational objectives for Irish doctoral programmes that are incorporated into the NFDE (Higher Education Authority, 2017). These objectives include research skills and awareness, ethics and social understanding, communication skills, personal effectiveness/development, team working and leadership, career management, and entrepreneurship and innovation.

10 Only on successful completion of the transfer are students enrolled as doctoral students. Not all HEIs refer to this stage as a transfer. Some call it 'differentiation' whilst others refer to the process as 'confirmation'.

11 There was variation in this, both in terms of content and degree title. For example, in one HEI a doctoral student was first enrolled to a Diploma in Academic Practice, in another they were enrolled on a Master of Research programme, in another a Master of Literature. 